\title{
Música y postmodernidad: unas notas sobre Philip Glass
}

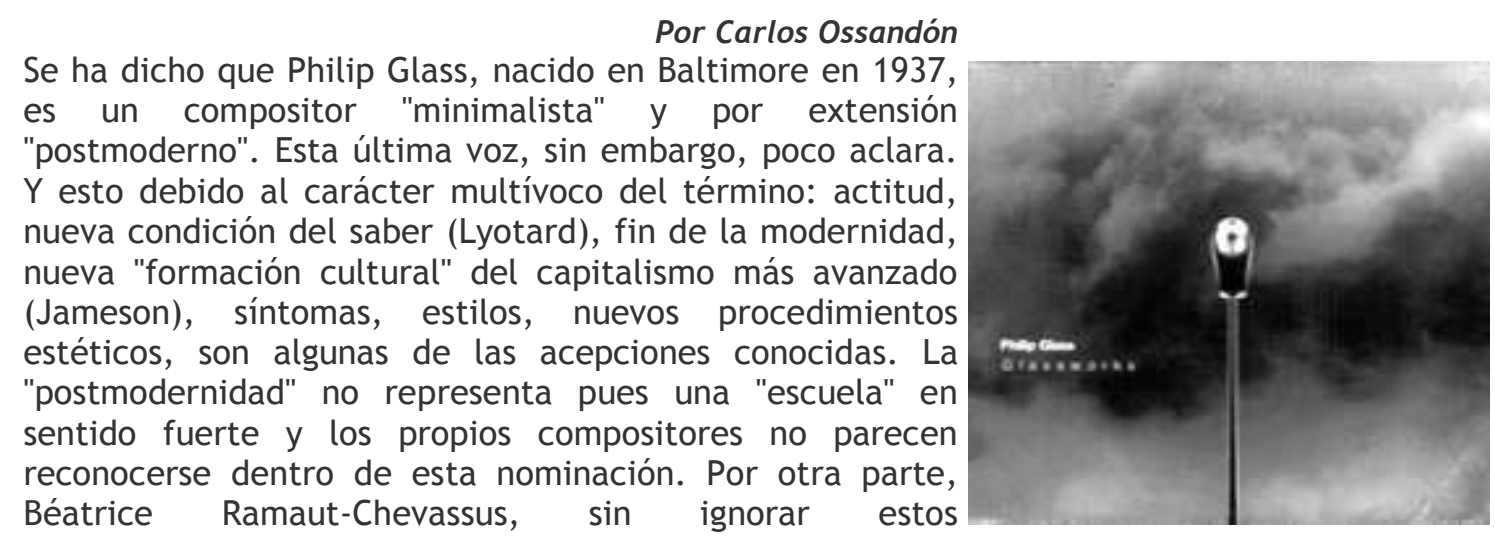
inconvenientes, señala que "una interrogación sobre los lazos entre música y postmodernidad se legitima por un conjunto de tendencias, que emergen desde fines de los 60 (declive de las vanguardias, voluntad de rememoración, fisura de los sistemas totalizadores, heterogeneidad de los elementos...)", que adquieren un cierta "coherencia" que se expresa en músicas de naturaleza muy diversa (Musique et postmodernité). Inspirándome en esta conexión intentaré articular sólo un par de "notas" sobre Philip Glass.

Digo sólo un par de rápidas notas, soslayando intencionadamente un examen mucho más largo que buscaría poner en tensión a la luz de ciertas composiciones actuales, Philip Glass entre otros, una serie de tópicos postmodernos tales como el redescubrimiento de lo étnico y de lejanas culturas, el eclecticismo o la hibridez, el imperio de las citas, etc.

¿Qué me ha llamado principalmente la atención de las obras de este compositor norteamericano? En primer lugar, la sensación de estar delante de unas obras que parecen tener más que ver con el mundo de las "formas" y de las "percepciones" que de los "misterios", "sentimientos" o "ideas", si cabe hablar así en música. Escuchando "Islands", por ejemplo, la tercera pieza de Glassworks (Sony, Made in Austria, 2000), se aprecia algo bastante estructurado, casi geométrico, donde el azar no reina, tampoco unas discontinuidades como las de John Cage, pero sí unas "repeticiones" (elemento importante en Glass) que serían difícilmente aceptadas por otras sensibilidades musicales. En la pieza siguiente, "Rubric", hay un cambio brusco en la velocidad o tempo, se vuelve más juguetona o alocada, pero las "repeticiones" se mantienen y el carácter "geométrico" y propiamente "perceptual" de la composición también. ¿Qué escuchamos pues? Unas "formas" muy nítidas, sin pretensiones "trascendentes" o que no buscan arrojar "mensajes", que se agotan en tanto "significantes" libres, no "atados" a ningún "contenido"; "formas" que nos invitan a "percibir" más que a "soñar". La pieza siguiente, "Facades", si bien aparentemente más "melancólica" y de hecho más "melodiosa", no alcanza, sin embargo, a expresar un "alma"; está lejos de las diversas modulaciones que en este plano exhibieron los románticos decimonónicos y también del tipo de trabajo que manifiesta el estonio Arvo Pärt, quizá también algo "minimalista" pero cuya "economía de medios" no se sustrae a una "espiritualidad" o a unas densidades culturales o religiosas que no están ciertamente en las obras más "exteriores", "formales" o directamente "perceptuales" de Glass.

Un segundo punto de interés, que no es sino una ampliación de lo ya dicho, se vincula menos con las composiciones mismas de Glass y más con lo que podríamos llamar, apoyándonos en Walter Benjamin, el sensorium, es decir, los modos específicos de percepción que pudieran precipitar o llevar implícitos estas composiciones. Advirtamos sí que situados en este plano sólo cabe suponer unas determinadas reacciones. Instalados pues del lado del "receptor", estas "formas" sin "mensajes", cuyas fuerzas radican en sus propias "inmanencias", parecen proyectar ya no "sentimientos" o grandes ensoñaciones sino antes bien "intensidades" o incluso 
"energías". Al parecer estas proyecciones estarían "naturalmente" adscritas a unas piezas que carecerían de "subtextos" o que no serían concebibles como la mera superficie de resonancia de unas "experiencias" que desde fuera las determinaría. Estas "energías" que las obras de Glass proyectan no llevan consigo ningún afán crítico o paródico de las afecciones clásicas o modernas. Que esta aparente "neutralidad" subjetiva sea mejor o peor que lo que precipitan otras composiciones del repertorio "culto" es, me parece, "harina de otro costal". 